\section{Immiscible melts associated with recycled ocean crust at Fogo, Cape Verde}

\author{
MS. ELIN M RYDEBLAD ${ }^{1}$, ABIGAIL K BARKER ${ }^{2}$, JANE \\ BARLING $^{3}$, BEN S ELLIS ${ }^{4}$, HAOCHEN DUAN $^{5}$, \\ VALENTIN R TROLL ${ }^{2}$, FRANCISCO J PÉREZ TORRADO ${ }^{6}$, \\ JUAN C CARRACEDO ${ }^{6}$ AND PAUL MARTIN HOLM ${ }^{7}$ \\ ${ }^{1}$ Imperial College London \\ ${ }^{2}$ Uppsala University \\ ${ }^{3}$ Oxford University \\ ${ }^{4}$ ETH Zürich \\ ${ }^{5}$ Uppsala university \\ ${ }^{6}$ Universidad de Las Palmas \\ ${ }^{7}$ University of Copenhagen \\ Presenting Author: jane.barling@earth.ox.ac.uk
}

The island of Fogo, Cape Verde is a prime candidate for tracing mantle processes as the Cape Verde archipelago is situated on unusually thick lithosphere. This geological setting has been argued to provide the best opportunities to tap the most fertile mantle lithologies without diluting their signals with high degrees of partial melting. Additionally, the presence of carbonatites in the Cape Verde archipelago supports the presence of carbonated lithologies in the mantle source.

This study investigates the trace element and $\delta^{60 / 58} \mathrm{Ni}$ isotope composition of whole rock samples in a suite of volcanic rocks from Fogo, Cape Verde. These data are combined with trace element compositions of olivine and clinopyroxene phenocrysts and major elements from melt inclusions. We aim to unravel the processes of melt immiscibility and mantle-melt reactions occurring deep in the mantle source, as well as characterising the contributing mantle lithologies.

This study finds that $\delta^{60 / 58} \mathrm{Ni}$ correlates negatively with $\mathrm{Ba} / \mathrm{Nb}$ and positively with $\mathrm{Th} / \mathrm{U}$. This indicates the presence of a sediment enriched source component with light $\delta^{60 / 58} \mathrm{Ni}$ values and low $\mathrm{Th} / \mathrm{U}$; the latter possibly reflecting the presence of metasomatic clinopyroxene [1].

The melt inclusions form two populations where the dominant group is a felsic, highly alkaline-phonolitic melt and the other is ultramafic/mafic, with low silica and alkali content (Fig). This bimodality is further observed in the olivine and clinopyroxene mineral chemistry, where olivine has low $\mathrm{Ni}$ compared to clinopyroxene, which is the main Ni hosting phase. Additionally, clinopyroxene compositions are similar to those hosted by pyroxenites from the adjacent island of Brava. In contrast, olivine compositions share features with the mineral compositions of Brava carbonatites.

This study suggests that minerals and melt inclusions in Fogo lavas preserve evidence of immiscible melts of phonolitic, pyroxenitic, and possibly carbonatitic compositions. The minerals and their host melts were aggregated to form hybridised magmas. The phonolitic melt may be derived from eclogitic source rocks, whereas the ultramafic/mafic melt resembles melts derived from carbonated peridotite.

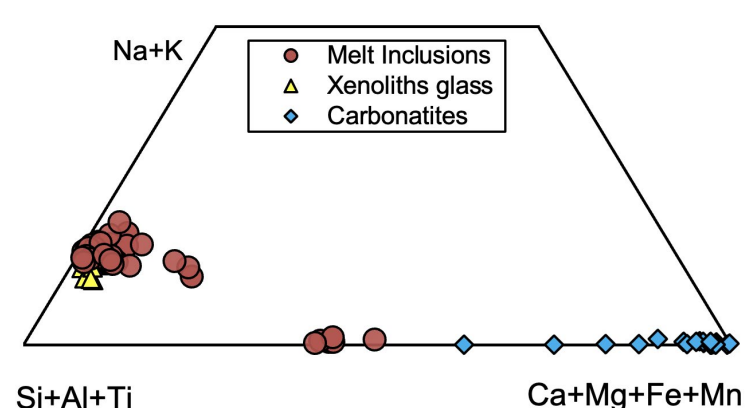

$\mathrm{Si}+\mathrm{Al}+\mathrm{Ti}$ 